\title{
DESAIN SMART BODY VEST UNTUK MEMINIMALISIR KECELAKAAN KERJA MENUJU INDONESIA ZERO ACCIDENT
}

\author{
Mohammad Iskandar Nur Fahmi ${ }^{1}$, Muhammad Bagus Panuntun², \\ Andayani Yuwana Sari ${ }^{3}$, Febri Liantoni ${ }^{4}$ \\ 1,2,3Keselamatan dan Kesehatan Kerja, Universitas Sebelas Maret \\ ${ }^{4}$ Pendidikan Teknik Informatika dan Komputer, Universitas Sebelas Maret \\ E-mail: iskandarnurfahmi21@gmail.com, bagusp@gmail.com, andayaniyuwana@gmail.com, \\ febri.liantoni@gmail.com
}

\begin{abstract}
Design Of Smart Body Vest To Minimize Work Accident Towards Indonesia Zero Accident. The construction sector plays an important role in a country's economy. This is because construction projects such as the construction of buildings, roads, bridges and other infrastructure are one of the benchmarks of economic progress and civilization of a country. Work accidents on construction projects can cause work to stop and result in financial losses and decreased work productivity. According to the Minister of Manpower in 2018 the number of work accidents has increased from the previous year even from the data of the Central Statistics Agency stating that the majority of construction workers are junior high school graduates and below. This is one of the factors causing the increase in occupational accidents in the construction sector. Losses from work accidents are also included in workers' losses, damage to equipment and materials wasted due to work accidents. Occupational health and safety (K3) risk control is very important as a preventive effort to prevent a bigger event. One such control is the use of Personal Protective Equipment (PPE) or more commonly called personal protective equipment (PPE). The existence of PPE is important for workers to minimize the impact of accidents so that each company is obliged to use PPE. This study aims to minimize the number of work accidents in Indonesia, especially in the construction sector. The method used in making the body vest is the addition of an airbag by applying the fall detection algorithm to the K-Nearest Neighbor $(K N N)$, which is to calculate the Euclidean distance which is the distance between the sample and training data and then determine the $k$ nearest data from the sample so that the sample can be classified on the sensor and microcontroller. The way it works is when a collision or a hard collision occurs, workers will generally be thrown or dropped then there will be a change in the acceleration of the position of the body wearing a body vest. The change in acceleration triggers the development of airbags on the body vest. This is expected to reduce injuries to vital organs in the worker's body.
\end{abstract}

Keywords: Personal Protective Equipment; Body Vest; Microcontroller; Work Accident; K-Nearest Neighbor

\begin{abstract}
Abstrak: Desain Smart Body Vest Untuk Meminimalisir Kecelakaan Kerja Menuju Indonesia Zero Accident. Sektor konstruksi memegang peranan penting bagi perekonomian suatu negara. Hal ini karena proyek konstruksi seperti pembangunan gedung, jalan, jembatan dan infrastruktur lainnya merupakan salah satu tolok ukur kemajuan ekonomi dan peradaban suatu negara. Kecelakaan kerja pada proyek konstruksi dapat menyebabkan pekerjaan terhenti dan mengakibatkan kerugian financial serta menurunnya produktifitas kerja. Menurut Menteri Ketenagakerjaan pada tahun 2018 angka kecelakaan kerja mengalami peningkatan dari tahun sebelumnya bahkan dari data Badan Pusat Statistik menyatakan bahwa sebagian besar pekerja konstruksi adalah tamatan SMP kebawah. Hal ini merupakan salah satu faktor penyebab meningkatnya kecelakaan kerja dalam sektor konstruksi. Kerugian dari kecelakaan kerja juga termasuk dalam kerugian pekerja, biaya kerusakan peralatan dan material terbuang akibat terjadinya kecelakaan kerja. Pengendalian risiko keselamatan dan kesehatan kerja (K3) menjadi sangat penting sebagai usaha preventif mencegah terjadinya kejadian yang lebih besar. Salah satu pengendalian yang dimaksud adalah penggunaan Personal Protective Equipment (PPE) atau yang lebih sering disebut alat pelindung diri (APD). Keberadaan APD
\end{abstract}


menjadi penting bagi pekerja guna meminimalisir dampak kecelakaan sehingga setiap perusahaan wajib menggunakan APD. Penelitian ini bertujuan untuk meminimalisir angka kecelakaan kerja di Indonesia terutama pada sektor konstruksi. Metode yang digunakan dalam pembuatan body vest adalah penambahan airbag dengan menerapkan algoritma fall detection dengan K-Nearest Neighbor (KNN) yaitu menghitung Euclidean distance yang merupakan jarak antara sample dan data training kemudian menenentukan sebanyak $K$ data terdekat dari sample, sehingga sample dapat diklasifikasikan pada sensor dan mikrokontroler. Cara kerjanya adalah pada saat terjadi tabrakan atau benturan keras, umumnya pekerja akan terlempar atau terjatuh kemudian terjadi perubahan akselerasi posisi badan yang mengenakan body vest. Perubahan akselerasi tersebut menjadi pemicu mengembangnya airbag pada body vest. Hal ini diharapkan dapat mengurangi cidera pada organ-organ vital dalam tubuh pekerja.

Kata Kunci: Alat Pelindung Diri; Body Vest; Mikrokontroler; Kecelakaan Kerja; K-Nearest Neighbor

\section{PENDAHULUAN}

Setiap kegiatan yang dijalankan oleh perusahaan sangat memerlukan sumber daya manusia. Meskipun telah didukung dengan peralatan berteknologi tinggi, kenyataannya peran manusia masih mendominasi pada setiap bagian di perusahaan. Tanpa peran manusia, proses bisnis di perusahaan tidak akan berjalan dengan lancar. Pada hakikatnya manusia memiliki akal, bakat, tenaga, keinginan, perasaan, dan perasaan yang tidak dapat digantiakan oleh teknologi. Potensi pada diri manusia tersebut perlu dikelola dan diperhatihan secara serius guna menunjang tercapainya visi dan misi tujuan perusahaan ${ }^{1}$.

Guna mendukung kelancaran dan kelangsungan perusahaan, meka keselamatan dan kesehatan para pekerja perlu diperhatikan. Undang- Undang Nomor 13 Tahun 2003 pasal 86 secara jelas telah menjelaskan hak-hak sebagai pekerja yaitu keselamatan dan kesehatan kerja, moral dan kesusilaan, perlakuan yang sesuai dengan nilai kemanusiaan

Dalam keberjalanannya sektor konstruksi memiliki tingkat kerentanan terhadap kecelakaan dan terpapar penyakit akibat kerja yang lebih tinggi dibanding sektor lainnya. Kondisi tersebut mengharuskan setiap pekerjaan konstruksi melakukan pemenuhan terhadap peraturan serta persyaratan diantaranya sisi keselamatan, kesehatan, aspek teknik, keamanan, perlindungan terhadap tenaga kerja, dan tata kelola lingkungan untuk memastikan tidak adanya kerusakan lingkungan yang diakibatkan oleh pekerjaan konstruksi ${ }^{2}$.

Sektor konstruksi merupakan bidang yang memiliki peran besar untuk menunjang perekonomian nasional. Pembangunan jalan, jeembatan, jalan tol, pelabuhan dimaksudkan untuk mendukung produktivitas rakyat dan meningkatkan daya saing ekonomi global. Jumlah tenaga kerja konstruksi pada tahun 2016 tercatat sejumlah 985.398, sedangkan pada tahun 2017 tercatat sejumlah 1.010.456, artinya ada peningkatan sejumlah 2,54 persen dibandingkan pada tahun sebelumnya. Data tersebut relevan mengingat potensi bahaya yang terdapat pada pekerjaan konstruksi sangat besar mulai dari terjatuh dari ketinggian, kejatuhan benda hingga benturan. Penggunaan teknologi air bag merupakan solusi untuk meminimalisir dampak benturan. NHTSA (National Highway Traffic Safety Administration) mencatat dari 1987 hingga 2017, kantung udara frontal menyelamatkan 50.457 nyawa.

Pekerjaan operator kendaraan berat proyek seperti, excavator, compactor, dozer memiliki risiko besar terhadap benturan apabila terjadi kecelakaan. Tidak tersedianya air bag pada kendaran berat proyek semakin memperbesar risiko cidera akibat benturan saat terjadi kecelakaan. Kondisi demikian perlu untuk dilakukan pengendalian salah satu jenis pengendalian diantaranya penggunaan Alat Pelindung Diri (APD). Salah satu APD 
yang sering dikenakan pekerja adalah body vest. Rekayasa pada body vest dapat dilakukan dengan menerapkan teknologi airbag. Pada penelitian T. N. Shaikh dkk menjelaskan bahwa material penyusun airbag sebagian besar berupa kain nilon. Cara kerja airbag dengan berbagai sensor yang terhubung dalam ACU (Airbag Control Unit). Apabila terjadi benturan atau kecelakaan sensor akan mengirim pesan kepada ACU yang kemudian menyebabkan airbag bekerja. Kesimpulan pada penelitian tersebut menunjukkan bahwa terjadi penurunan angka kecelakaan lalu lintas setelah pengembangan teknologi airbag. Teknologi airbag pada dasarnya telah dikembangkan khususnya pada indudtri kendaraan mobil. Dengan adanya sistem airbag, saat terjadi benturan operator kendaraan berat proyek dapat terhindar dari cidera akibat benturan saat kecelakaan ${ }^{3}$. Penelitian oleh Chien-Liang melakukan fall detection menggunakan $K$ Nearest Neigbor (KNN) berdasarkan identifikasi tubuh manusia. Penelitian membahas mengenai posisi tubuh saat berdiri, duduk dan tidur terlentang 4 . Pada penelitian sebelumnya KNN pernah digunakan untuk melakukan klasifikasi daun berdasarkan fitur moment invariant. Dari penelitian ini diperoleh akurasi sebesar $86,67 \%$.

Pada penelitian ini akan dilakukan perancangan smart body vest yang dilengkapi dengan sistem airbag berbasis sensor yang dapat mendeteksi benturan. Sensor bekerja dengan metode pengklasifikasian K-Nearest Neighbour. Cara untuk meningkatkan efisiensinya metodenya dengan menemukan sample yang mewakili seluruh data training untuk klasifikasi benturan atau bukan.

\section{BAHAN DAN CARA PENELITIAN}

Jenis penelitian yang digunakan yaitu penelitian kepustakaan (library research). Jenis penelitian ini merupakan penelitian dengan mengumpulkan data pustaka yang dapat diambil dari jurnal ilmiah 6. Penelitian kepustakaan atau kajian literatur (literature review, literature research) merupakan penelitian dengan mengkaji atau meninjau informasi pengetahuan, gagasan ide, atau temuan yang terdapat di dalam jurnal dengan orientasi akademik. Fokus penelitian ini adalah dengan menemukan berbagai macam teori, pedoman hukum, dalil, prinsip, atau ide gagasan yang berguna untuk menganalisis dan memberikan jawaban terhadap pertanyaan yang dirumuskan ${ }^{7}$.

Data yang digunakan pada penelitian ini merupakan data sekunder, dimana data yang diperoleh secara tidak langsung atau data dari pihak lain. Tetapi data tersebut diperoleh dari hasil penelitian yang dilakukan dari penelitian terdahulu. Sumber data sekunder yang didapatkan dari buku dan laporan ilmiah primer atau data orisinil yang terdapat dalam artikel atau jurnal tertulis maupun tidak tertulis. Perolehan sumber data utama penelitian ini dikutip dari jurnal yang dibuat oleh Amallo dkk mengenail penerapan algoritma fall detection yang diletakkan pada smart helmet dengan menggunakan accelerometer sebagai pemicunya ${ }^{8}$. Jurnal tersebut menjadi sumber utama data yang dipilih oleh penulis dengan dikarenakan memiliki hubungan dengan rumusan masalah dalam penelitian ini. Pada penelitian ini dirancang penerapan algoritma fall detection dengan menggunakan metode $K$ Nearest Neighbor (KNN). Metode KNN dilakukan dengan membandingkan data uji dengan data training. Salah salah tahap awal yang harus terpenuhi dengan menentukan jumlah nilai $\mathrm{K}$ 4,5.

Analisis yang digunakan adalah analisis deskriptif yang menggunakan metode analisis data dengan menggambarkan data-data yang sudah dikumpulkan. Sistem kerja yang digunakan smart body vest ditunjukkan pad Gambar 


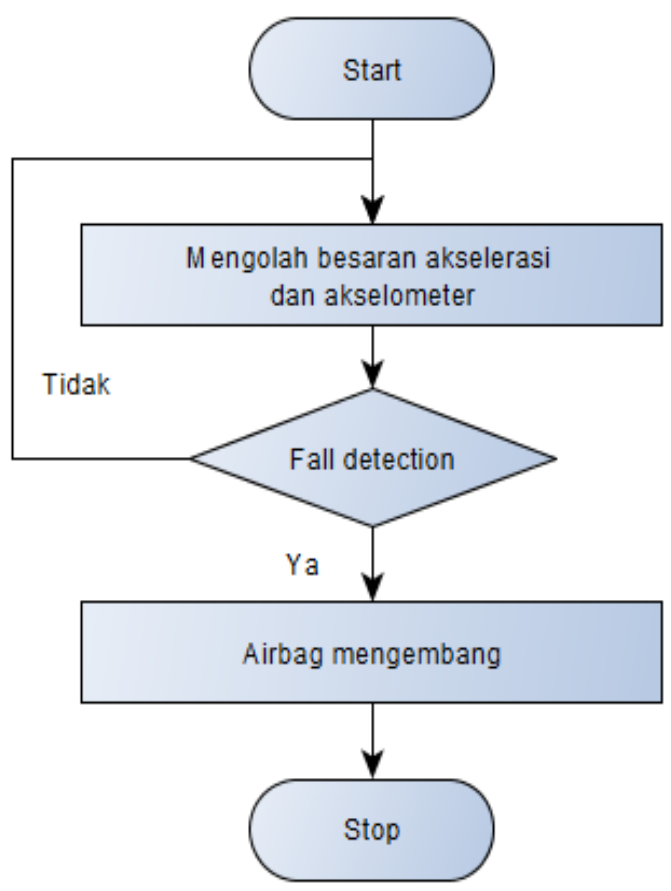

Gambar 1. Sistem Smart Body Vest

\section{HASIL PENELITIAN DAN PEMBAHASAN}

Hasil penelitian dipaparkan dalam bentuk diagram desain Smart Body Vest yang merupakan ringkasan dari hasil penelitian. Dengan penyajian sederhana dengan harapan mempermudah pembaca dalam memahami hasil penelitian.

\section{Perancangan Alat}

Pada Gambar 2 dijelaskan bahwa teknis dari sensor accelerometer dengan mendeteksi sudut dari pengguna dan disalurkan ke mikrokontroller arduino. Mikrokontroller mengolah masukan dari sensor dan memberikan keluaran ke relay. Ketika sensor mendeteksi adanya kecelakaan maka mikrokontroller akan memerintahkan relay untuk menghidupkan alat sehingga airbag dapat mengembang.
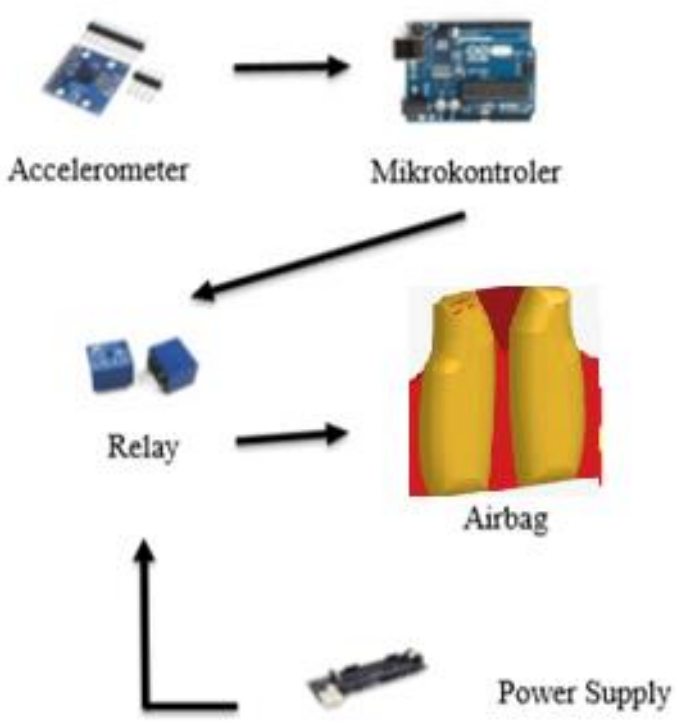

Gambar 2. Perancangan alat 


\section{Cara Kerja Alat}

Desain cara smart body vest yang dikembangkan menggunakan metode $K$-Nearest Neigbor (KNN) sebagai penentu terjadinya aktivitas terjatuh atau tidak. Hasil dari KNN kemudian dijadikan acuan untuk mengaktifkan airbag saat terjadi kecelakaan. Tahapan cara kerja alat berdasarkan metode KNN ditunjukkan dalam Gambar 3 berikut.
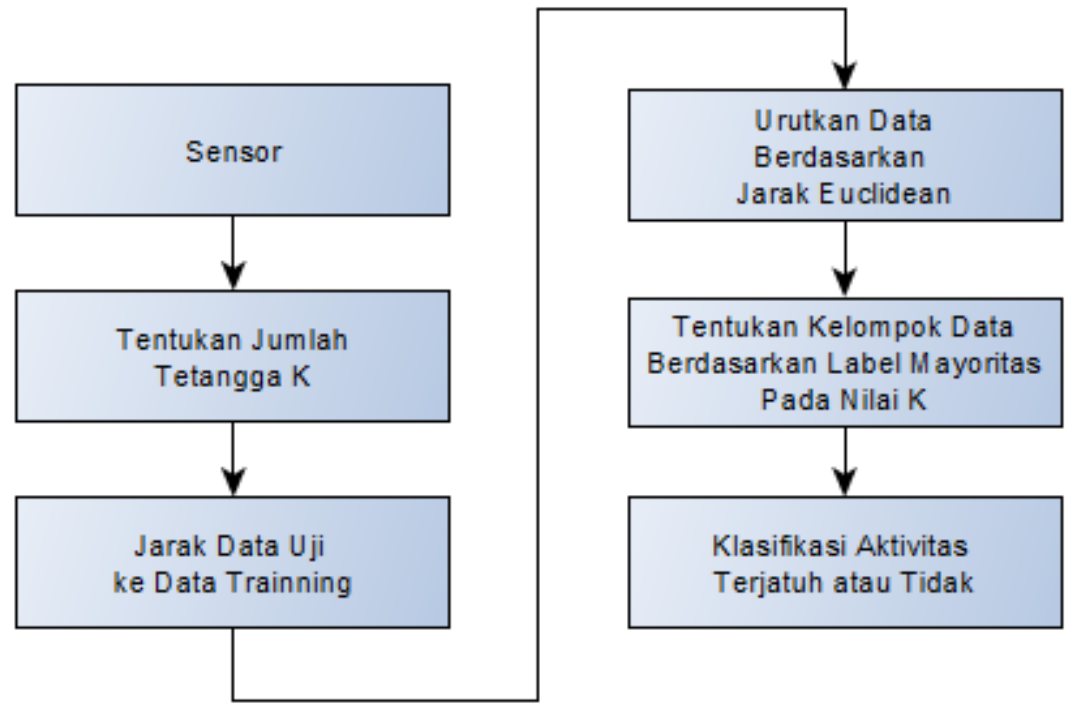

Gambar 3. Tahapan cara kerja alat berdasarkan metode KNN

Cara kerja pada smart body vest meliputi :

1. Body vest menerima sebuah besaran akselerasi dari akselerator yang akan dibawa ke arduino. Kemudian besaran tersebut akan di klarifikasi menggunakan metode KNN.

2. Pada proses klasifikasi oleh metode KNN, akan ditentukan apakah aktivitas tersebut merupakan aktivitas terjatuh atau tidak.

3. Jika KNN mengklasifikasi aktivitas tersebut bukan aktivitas terjatuh, maka sinyal akan berhenti atau tidak diteruskan. Sedangkan jika hasil klasifikasi menyatakan bahwa aktivitas tersebut merupakan potensi terjatuh, maka arduino akan meneruskan sinyal ke relay untuk mengembangkan airbag.

4. Airbag mengembang dalam jangka waktu 0,04 detik setelah sinyal disampaikan ke relay yang mengembangkan airbag.

\section{Desain Smart Body Vest}

Bahan pada airbag yang digunakan adalah kain Nilon 6,6 yang biasa digunakan untuk airbag pada umumnya. Bahan kimia yang direaksikan adalah gas Kalium Nitrat (KNO3) dan Natrium Azida (NaN3) untuk menghasilkan gas nitrogen, sehingga airbag dapat mengembang dengan kecepatan $300 \mathrm{kph}$ selama 0,04 detik. Hasil desain smart body vest seperti ditunjukkna pada Gambar 4-7 

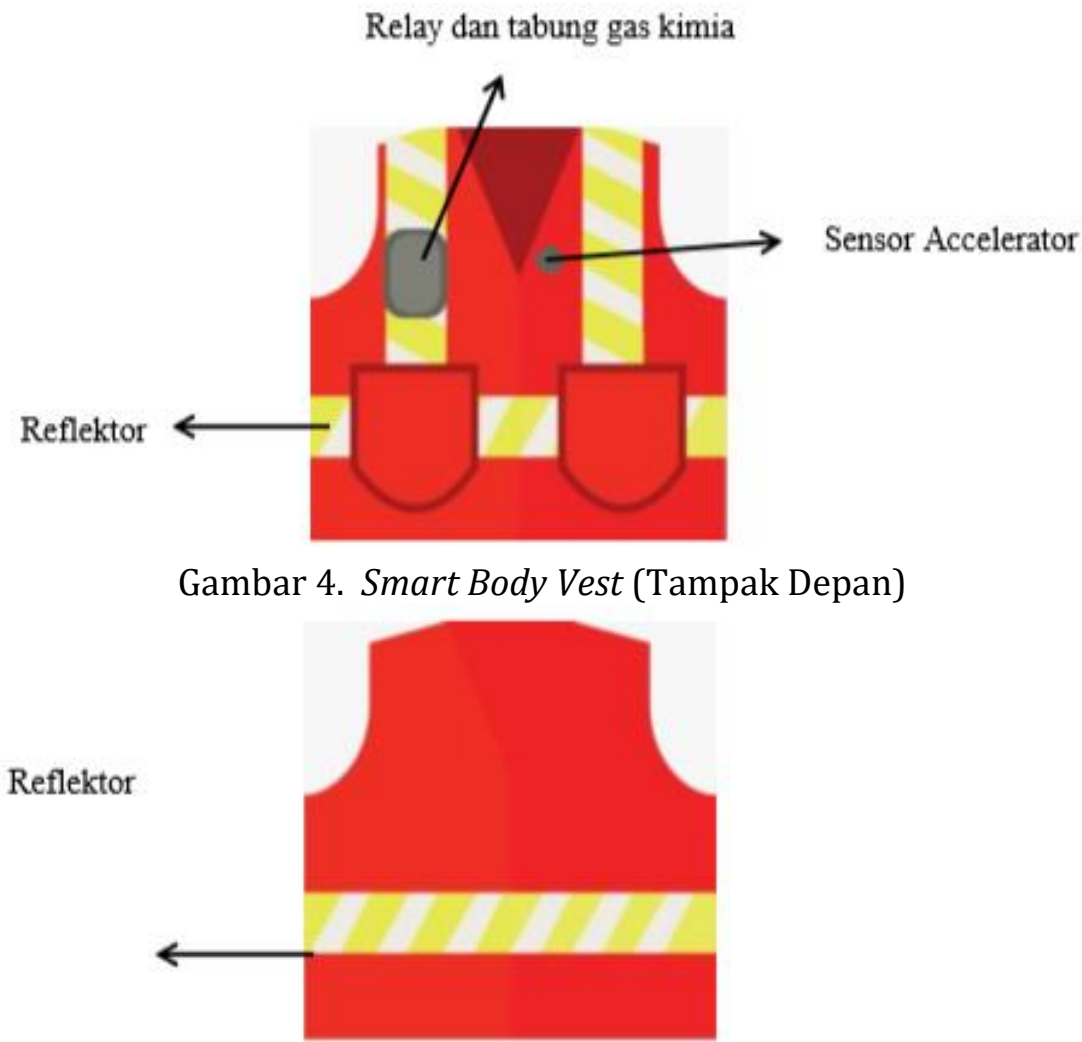

Gambar 5. Smart Body Vest (Tampak Belakang)

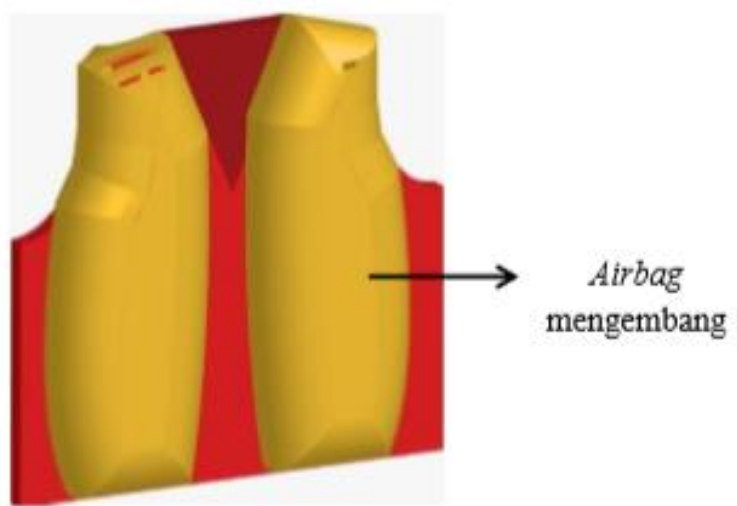

Gambar 6. Smart Body Vest (Mengembang Tampak Depan)

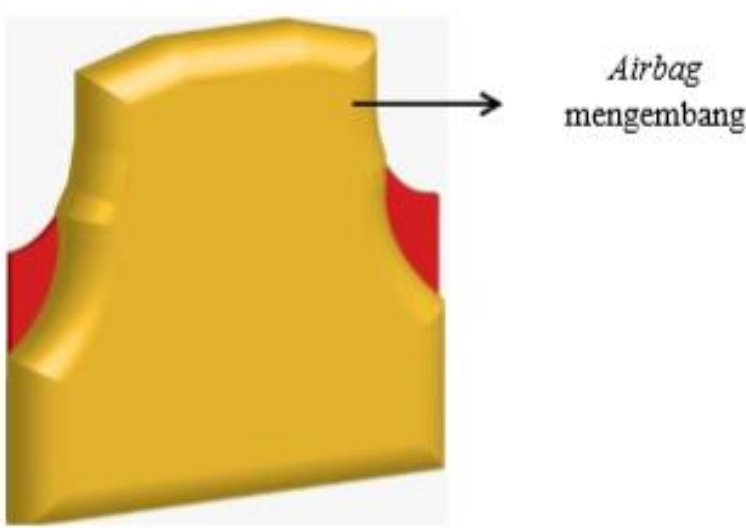

Gambar 7. Smart Body Vest (Mengembang Tampak Belakang) 


\section{Kelebihan dan Kekurangan Alat}

Kelebihan dari smart body vest dibandingkan dengan body vest lainnya adalah kemampuan untuk melindungi tubuh dari benturan. Body vest pada umumnya hanya sebagai penanda pada pekerja, sedangkan smart body vest mampu menahan benturan. Waktu pengembangan airbag relatif singkat yaitu dengan kecepatan $200 \mathrm{mph}$ atau sekitar $0,04 \mathrm{~s}$. Dengan waktu yang singkat maka risiko benturan dapat diminimalkan. Penggunaan bahan kain Nilon 6,6 yang kuat, dan elastis sehingga tidak mudah rusak. Adapun kekurangan dalam smart body vest ini adalah penggunaan gas Kalium Nitrat (KNO3) dan Natrium Azida (NaN3) hanya dapat digunakan sekali pakai. Harapan pada penelitian kedepannya yaitu adanya pengembangan rancangan sistem yang lebih baik.

\section{KESIMPULAN}

Pembuatan smart body vest sangat bermanfaat sekali bagi sektor konstruksi di Indonesia dan smart body vest ini merupakan salah satu Alat Pelindung Diri yang selalu dipakai pekerja konstruksi sehingga sangat mudah dalam hal pengaplikasiannya dalam sektor konstruksi. Berdasarkan perolehan hasil penelitan dan analisis, dapat diambil kesimpulan sebagai berikut :

1. Smart body vest memiliki tujuan untuk meminimalisir tingkat kecelakaan kerja terutama pada sektor konstruksi.

2. Smart body vest mampu mengembang dengan waktu yang relatif singkat yaitu dengan kecepatan $200 \mathrm{mph}$ atau sekitar 0,04 s.

3. Bahan pada airbag yang digunakan adalah kain Nilon 6,6 yang biasa digunakan airbag pada umumnya sehingga cocok untuk smart body vest ini. Bahan kimia yang direaksikan adalah gas Kalium Nitrat (KNO3) dan Natrium Azida (NaN3) untuk menghasilkan gas nitrogen.

4. Metode KNN dengan menghitung Euclidean distance antara sample dan data training sangat efektif digunakan untuk smart body vest ini.

\section{KEPUSTAKAAN}

1. Bruno L. Perlindungan Keselamatan Dan Kesehatan Kerja Terhadap Tenaga Kerja. J Ilm ilmu Huk. 2019;53(9):1689-1699.

2. UU-No.18. Undang-Undang Nomor 18 Tahun 1999 Tentang Jasa Konstruksi.; 1999.

3. Shaikh TN, Chaudhari S, Rasania H. Air Bag: A Safety Restraint System of an Automobile. Int J Eng Res Appl. 2013;3(5):615-621.

4. Liu CL, Lee CH, Lin PM. A fall detection system using k-nearest neighbor classifier. Expert Syst Appl. 2010;37(10):7174-7181. doi:10.1016/j.eswa.2010.04.014

5. Liantoni F. Klasifikasi Daun Dengan Perbaikan Fitur Citra Menggunakan Metode K-Nearest Neighbor. Ultim J Tek Inform. 2015;7(2):98-104.

6. Hadi S. Metodologi Research. Yogyakarta: Fak.Psikologi UGM; 1990.

7. nursapia nursapia. PENELITIAN KEPUSTAKAAN. IQRA' $J$ Ilmu Perpust dan Inf. 2014;8(1):68-73. doi:10.30829/IQRA.V8I1.65

8. Amallo DA, Sudiharto DW, Putrada AG. Penerapan Algoritma Fall Detection pada Inflatable Smart Helmet Menggunakan Accelerometer. Proc Eng. 2018;5(3):7894-7901. 
